\title{
The Analysis of Investment Environment and Foreign Direct Investment Prognostication: Lithuanian Case
}

\author{
Ligita Gaspareniene, Mykolas Romeris University
}

\begin{abstract}
The aim of this article is to research the investment environment and to prognosticate the trends of FDI in Lithuania. The methods of the research include systematic and comparative analysis of the scientific literature and linear regression and trend analysis. The results of the research have revealed that the trend and amount of FDI in Lithuania strongly correlate. The linear regression equation is also growing, which proposes that over the next two years FDI in Lithuania should increase.
\end{abstract}

Keywords - Foreign direct investment (FDI), FDI prognostication, investment environment, Lithuania.

\section{INTRODUCTION}

During the two recent decades, the process of globalization has determined a steep growth of foreign direct investment (FDI), which is considered to be one of the main determinants of economic development in the host country regarding the creation of new work places, implementation of new technologies and accumulation of technical experience (Alam \& Shah, 2013; Goswami \& Heider, 2014; Kok \& Ersoy, 2009; Mucuk \& Demirsel, 2013; Rao, 2010). With reference to the Central Bank of the Republic of Lithuania (2013), FDI consists of equities (stock, real estate, reserves), reinvestment (the part of the direct investor's profit, which was not distributed by the parent or partner company in the form of dividends) and obtained debt instruments (loans, bonds, trade credits, forwards and other receivables). Through the components mentioned above FDI has a direct impact on economic potential of the country.

In the increasing competition among countries for forces of investment attraction most of them put effort in the creation of investment-favourable environment (Agrawal \& Khan, 2011). FDI attraction is an important indicator determined by political, economic and social environment in the country, i.e. investment climate (Rogmans \& Ebbers, 2013; Alam \& Shah, 2013). The governments pursue particular policies considering international business and face the necessity to select the right policy of capital intensification to create favourable conditions for international corporations to integrate in domestic markets and to expand their production. Thus, each country should evaluate its opportunities to attract FDI and to create the investment-favourable environment.

This article is aimed at researching the investment environment and prognostication of the trends of FDI in Lithuania. The aim has been detailed into the following objectives: 1) with reference to the scientific literature, to assess the factors of Lithuanian investment environment; 2) to perform comparative analysis of Lithuanian investment environment and the investment environment in the Baltic States - Latvia and Estonia; 3) to apply the method of trend analysis to prognosticate the trends of FDI in Lithuania; 4) with reference to the research results, to review the opportunities of FDI promotion in Lithuania. Methods of the research include systematic and comparative analysis of the scientific literature and trend analysis.

\section{THE ASSESSMENT OF THE FACTORS OF LITHUANIAN INVESTMENT ENVIRONMENT}

The term "investment climate" is rather widely used in the scientific literature. It is interpreted as a complex of factors that are typical of a particular location and make impact on its development (Misunas \& Gudeliauskaite, 2013). It can be stated that a favourable investment climate enables not only profit earning but also forms the conditions for the creation of new work places, price reduction and social improvement (United Nations, 2014). The set of the traditional economic factors such as stable macroeconomic environment, educated and cheap labour force and strategic geographic position is necessary, but insufficient. The assessment of the investment environment also has to include such factors as steadiness of legal regulation (particularly regarding investment activities), tax policy, business registry system, labour relations and infrastructure (Mucuk \& Demirsel, 2013; Alam \& Shah, 2013.

Over the past few years Lithuanian investment climate has significantly improved: with reference to the World Bank ratings, Lithuania ranks 17 th among 189 countries by the attractiveness of the investment climate (World Bank, 2014). The comparative analysis of the positive and negative features of Lithuanian investment climate is presented in Table I.

TABLE I

THE COMPARATIVE ANALYSIS OF THE FEATURES OF LITHUANIAN INVESTMENT CLIMATE (COMPILED BY THE AUTHOR)

\begin{tabular}{|c|c|}
\hline Positive Features & Negative features \\
\hline $\begin{array}{l}\text { - Lithuanian is a fast-growing } \\
\text { economy with diversified } \\
\text { economics, skilled labour force, } \\
\text { low profit tax, developed } \\
\text { infrastructure, stable political } \\
\text { system; } \\
\text { - The country is a EU member } \\
\text { located next to the East European } \\
\text { countries; } \\
\text { - Lithuanian laws and regulations } \\
\text { provide equal protection for both }\end{array}$ & $\begin{array}{l}\text { - Income level in the country is } \\
\text { lower than the EU average which } \\
\text { determines the regulation of the } \\
\text { prices of new products; } \\
\text { - Significant part of Lithuanian } \\
\text { population emigrate to foreign } \\
\text { countries; } \\
\text { - High inflation of wages; } \\
\text { - Relatively inefficient } \\
\text { bureaucracy, high level of } \\
\text { corruption and lack of }\end{array}$ \\
\hline
\end{tabular}




\begin{tabular}{|c|c|}
\hline Positive Features & Negative features \\
\hline foreign and domestic investment; & transparency in particular \\
- During the period of $2007-$ & industries can impede the \\
development of the country and \\
amounts of the EU support funds; & discourage investors. \\
- Foreign investors can invest in & \\
infrastructure. & \\
\hline
\end{tabular}

As it can be seen in Table I, Lithuanian investment climate can be treated as favourable due to the relatively high development of overall economics and infrastructure as well as the reliable legal system. However, low income level causing large emigration and inefficient bureaucracy are the spheres that need to be improved and strengthened in order to attract more foreign investment.

The creation of investment-favourable climate in the country is related to the steady legal regulation of investment activities. Lithuanian legal regulations ensure equal conditions for domestic and foreign investors, and almost all economic sectors are available for foreign investors. Even more, the government promotes investment by creating free economic zones with tax exemptions.

Tax policy is another influential factor while assessing the investment climate in the country. With reference to World Bank (2014), Lithuania ranks 56th among 189 countries by the efficiency of the tax policy. According to Novosinskiene (2013), tax exemption is ensured for newly-established enterprises in Lithuania. On the other hand, with reference to Tavares-Lehmann, Coelho and Lehmann (2013), tax exemption has lost its importance while creating investmentfavourable climate in developing economies, but investors do consider such factors as tax burden and the simplicity (complexity) of the tax system. Lithuanian profit tax (15\%) is treated as stable; it is becoming increasingly attractive and business-friendly. The real estate tax $(0.3-3 \%)$ is not considered to be high, although its calculation methodology is often treated as complicated and unfair. Since 2009, Lithuania has applied a rather attractive income tax tariff (15\%), which is one of the lowest in the EU. However, high and double labour income taxation not only has negative impact on new business establishment, competitiveness and employment but also increases the rate of shadow economy. The analysis of the scientific literature has revealed that the reduction of the tax burden in Lithuania is determined by faster GDP increase in comparison to taxable income (Misiunas \& Gudeliauskaite, 2013; Novosinskiene, 2013).

Although being improved over the last few years, Lithuanian business registry system could still be refined by simplifying and accelerating the procedures of business registration which can last for weeks (e.g., the establishment of the company of limited liability in Lithuania can take up to 5-10 days).

Lithuanian infrastructure is considered to be favourable for business performance and investment. With reference to Invest Lithuania (2014), the developers of service centres use the advantages of the well-developed IT infrastructure - the internet in Lithuania is one of the fastest in the EU; the country has prepared for the implementation of the "cloud computing" technology; the level of technology spread is high. What is more, Lithuania boasts of the well-developed logistic sector. For example, the sea port located in Klaipeda transports big quantities of cargos, the number of the flights from and to the country is increasing. All this contributes to the creation of investment-favourable environment.

Assessing labour relations in Lithuania, it should be noted that they are strictly regulated by the law. Limited work hours is one of the main barrier for the creation of flexible labour relations as well as for the opportunities of the remote working. What is more, non-wage labour costs are the highest in the Baltic region.

Skilled labour is one of the factors which is considered to be influential while investing in both production and service sectors. In this respect, Lithuania can be treated as an investment-attractive country due to the skilled labour force (93\% of the overall labour force have secondary or higher education, $52 \%$ know at least two foreign languages, employees are innovation-receptive and fast learning) (Misiunas \& Gudeliauskaite, 2013). However, in the context of the European Union, strict labour regulation is considered to be insufficiently flexible which causes numerous problems in the labour market, worsens business conditions and reduces international competitiveness of the country.

Summarizing, it can be stated that although the investment climate in Lithuania is considered to be favourable with a strong tendency of improvement (Cibinskiene \& Kontautiene, 2010), the volume of FDI during the period 2007 - 2013 varied in accordance with the economic cycle: in 2008, FDI in Lithuania decreased for more than $10 \%$ in comparison to 2007 as a result of the beginning of the economic recession; from 2009 to 2013, the volume of FDI in Lithuania increased by almost $20 \%$ as a result of the recovery of developed economies and investment promotion within the country during the post-crisis period (Lithuanian Department of Statistics, 2014). However, there still remain factors such as large emigration rate, inefficient bureaucracy, high labour taxation, complicated and prolonged business registry procedures, and inflexibility of labour relations that have to be improved and strengthened. The EU membership, as well as business globalisation contributes to the improvement of the investment environment. A country's attractiveness for investment depends on the capabilities of investment absorption which enables to achieve qualitative and quantitative level of the use of FDI (Geizutiene \& Sudzius, 2010; Santander Trade, 2014).

\section{COMPARATIVE ANALYSIS OF LITHUANIAN INVESTMENT ENVIRONMENT AND THE INVESTMENT ENVIRONMENT IN THE BALTIC STATES}

For more objective assessment of the investment environment in Lithuania, it is purposeful to compare it with the investment environment in the other two Baltic States Latvia and Estonia - that are similar to Lithuania by size and by the level of economic development.

Latvia is a small open economy where export makes one third of GDP. Corruption in this country still remains an 
$2015 / 27$

obstacle for attracting bigger volume of FDI, which causes problems to maintain the economic viability of the country (Misiunas \& Gudeliauskaite, 2013). Estonia is considered to be a modern market-oriented economy with the highest revenue per capita in the Baltic region. Estonian economy earns the largest part of revenue from electronics and telecommunications, develops relations with Finland, Sweden, Russia and Germany (Misiunas \& Gudeliauskaite, 2013). In Lithuania, FDI was the funding that enabled a rather fast transfer from command to market economy and contributed to the expansion of export markets (Indexmundi, 2013).

TABLE II

COMPARATIVE ANALYSIS OF INVESTORS' PROTECTION INDICATORS FOR THE BaLtic States (SANTANDER TRADE, 2014)

\begin{tabular}{|l|c|c|c|}
\hline Indicator & Lithuania & Latvia & Estonia \\
\hline $\begin{array}{l}\text { Transaction } \\
\text { transparency index }\end{array}$ & 7 & 5 & 8 \\
\hline $\begin{array}{l}\text { Manager's } \\
\text { responsibility index }\end{array}$ & 4 & 4 & 3 \\
\hline $\begin{array}{l}\text { Shareholders' power } \\
\text { index }\end{array}$ & 6 & 6 & 6 \\
\hline $\begin{array}{l}\text { Investors' protection } \\
\text { index }\end{array}$ & 5.7 & 5.7 & 5.7 \\
\hline
\end{tabular}

As it can be seen in Table II, Estonia has the highest transaction transparency index of all three Baltic States, which means that the investors' interests in this country are not only protected by the law, but also the conditions concerning particular investment are clearly defined in transaction agreements. Latvia has the lowest transaction transparency index which reveals the lowest reliability of the system of transaction establishment in comparison to the other two Baltic States. Lithuania, in this respect, takes the middle position. Manager's responsibility index is similar (3-4) for all three Baltic States. However, it is rather low in comparison to the index for the developed countries; for instance, manager's responsibility index for the USA is 9. Shareholders' power index is equal (6) for all three Baltic States, which reveals that shareholders can take legal actions with medium easiness. Investors' protection index is also equal (5.7) for all three Baltic States, which reveals a rather high level of the protection of investors' interests.

With reference to the ranking of the countries by "Ease of Doing Business" index (World Bank, 2014), Lithuania ranks 17 th among 185 countries all over the world, which is the highest position of the three Baltic States (Table III).

TABLE III

COMPARATIVE ANALYSIS OF THE EASE OF DOING BUSINESS INDICATORS FOR THE BALTIC STATES (WORLD BANK, 2014)

\begin{tabular}{|l|c|c|c|}
\hline Indicator & Lithuania & Latvia & Estonia \\
\hline $\begin{array}{l}\text { Ease of doing } \\
\text { business (rating) }\end{array}$ & 17 & 24 & 22 \\
\hline $\begin{array}{l}\text { Business } \\
\text { establishment } \\
\text { (rating) }\end{array}$ & 11 & 57 & 61 \\
\hline $\begin{array}{l}\text { Business } \\
\text { establishment (days) }\end{array}$ & 6.5 & 12.5 & 6.5 \\
\hline
\end{tabular}

\begin{tabular}{|l|c|c|c|}
\hline Indicator & Lithuania & Latvia & Estonia \\
\hline $\begin{array}{l}\text { Price (per cent per } \\
\text { (apita) }\end{array}$ & 0.9 & 1.9 & 1.5 \\
\hline $\begin{array}{l}\text { Business licences } \\
\text { (rating) }\end{array}$ & 39 & 79 & 38 \\
\hline Credit access & 28 & 42 & 3 \\
\hline Taxes & 56 & 32 & 49 \\
\hline Investors' protection & 68 & 68 & 69 \\
\hline
\end{tabular}

With reference to the World Bank (2014), business establishment and registry as well as obtaining permission for construction in Lithuania are the most complicated and prolonged in comparison to the other two Baltic States. What is more, the system of investors' protection in the country is rather weak. However, the conditions to register property, perform contracts and conduct international trade are more favourable.

The processes of closing a business and suspending a company are most complicated and prolonged in Latvia. However, credits and bank loans in this country are more accessible than in Lithuania or Estonia. Estonia has formed the most favourable conditions for tax paying: although tax tariffs in this country are the highest, the terms of business tax administration are not so complicated as in Lithuania and Latvia (Misiunas \& Gudeliauskaite, 2013).

Summarizing, it can be stated that the investment climate in a country reflects the factors that are considered to be the advantages of this country while making foreign investment. The comparative analysis of the investment environment in Lithuania, Latvia and Estonia has revealed that all three Baltic States take rather high positions by "Ease of doing business" indexes in the global context. Lithuania takes the highest position among the Baltic States, and its advantages are the favourable conditions to register property, perform contracts and conduct international trade, while complicated and prolonged business establishment and registry, difficulties obtaining permission for construction as well as the weak system of investors' protection can be considered as main disadvantages of Lithuanian investment environment.

\section{METHOdOLOGY OF THE RESEARCH}

The empirical research was based on the methods of linear regression and trend analysis. For the reflection of the quality of the linear equation, determination coefficient $R^{2}$ was engaged. Trend function, revealing the general tendency of the data increase or decrease, i.e. showing the dynamics and prognosis of the researched economic phenomenon, was calculated applying the methods of the lowest squares and regression analysis. For the evaluation of the trends of the researched phenomenon, the data showing FDI income in Lithuania during the period $2007-2013$ was engaged. For the verification of the calculation results, approximation error rate was applied. If $\mu$ does not exceed $10 \%$, the chosen mathematical expression very accurately describes variation tendencies; it is suitable for prognostication, and prognostication results can be treated as reliable. 


\section{PROGNOSTICATION OF FDI IN LITHUANIA}

FDI prognostication enables to forecast the dynamics of FDI in the future and reveal the plausible impact of FDI on economy (Boguslauskas, Bliekiene, Grondskis, \& Maksvytis, 2009). The linear regression equation $y=1723.1 x+29723$ shows the changes of FDI in Lithuania in the course of time. The prognostications have been made with reference to trend (polynomial) function $y=515.79 x^{2}-2403.2 x+35913$ (see Fig. 1).

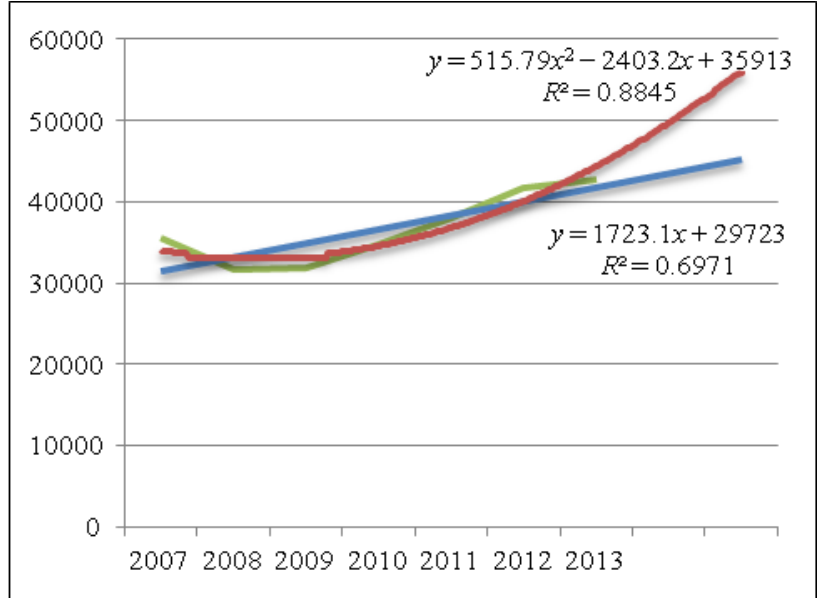

Fig. 1. FDI prognostication in Lithuania (compiled by the author with reference to the calculation results).

The rising curve of FDI shows the trend of FDI growing. The determination coefficient $R^{2}=0.8845$ shows that the trend and amount of FDI in Lithuania strongly correlate. The linear regression equation is also growing, which proposes that over the next two years FDI in Lithuania should increase. The determination coefficient $R^{2}=0.6971$ shows the normal link. The trend approximation coefficient is equal to 0.542 , thus, prognostication results can be treated as reliable. Also, the trend correlation coefficient is high, which proposes that there do not exist many other factors that can have a significant impact on the function.

On the global scale, it is prognosticated that FDI income during the period 2014 - 2015 should increase up to 1.8 billion dollars. It is considered that the increase of FDI income will be determined by the revival of the developed economies, global GDP, overall capital and trade. However, it should be noted that unequal growth, unpredictable turn of particular economies and the risk related to the USA "facilitation program" can reduce the volume of FDI during the period 2014 - 2015 (United Nations, 2014).

\section{OPPORTUNITIES OF FDI PROMOTION IN LITHUANIA}

Investment promotion is treated as initiation, attraction and implementation of new projects in the territory of the country, creation and maintenance of the investment-favourable legal and tax environment seeking to increase the global competitiveness of the country (Invest Lithuania, 2014).

First of all, FDI attraction opportunities are influenced by the economic development of other countries and the trends of global economic and political decisions. According to United Nations (2014), the global FDI should gradually increase during the period 2014 - 2015 due to the revival of the developed economies that can direct their resources to new investment. With reference to the Central Bank of the Republic of Lithuania (2013), the level of the use of production capacities is rather high in Lithuania, and this factor, in combination with favourable trends of global economic development, is considered to be one of the main drives for the investment increase. Further growth of investment is considered to be rather cloudy. The hardly predictable situation in the countries of the Eastern Europe can have negative impact on investors' expectations concerning further economic development. Nevertheless, short-term investment is expected to rise in 2014, but the rise is predicted not to be so steep as in 2013 .

With reference to EYGM Limited (2013), information technologies and communications, energy and utilities, pharmacy and biotechnologies will be the most attractive sectors for investment in Europe. What is more, it should be noted that production remains the main sector which generates the growth of European economy since $84 \%$ cent of the investors who participated in the research (EYGM Limited, 2013) were planning to continue production in Europe at least for further 10 years.

For the investment promotion in Lithuania, the government of the country has designed "The program of investment promotion and industrial development for 2014 - 2022" (the Government of the Republic of Lithuania, 2014). The program has been designed to establish the system of investment attraction and promotion in the Republic of Lithuania. The main aims of the program are FDI attraction to the country by improving the investment environment and creating an efficient system which would be directed towards the economic growth of the country. However, with reference to the analysis of the scientific literature, although the general investment environment in Lithuania is treated as favourable, Lithuania still remains insufficiently active while creating the image of a business and investment favourable country with numerous advantages (competitive profit tax, the largest domestic market in comparison to the other two Baltic States Latvia and Estonia, high-skilled labour force and others). Due to this reason, the country fails to attract as many investors as it could.

In order to improve the business and investment environment in Lithuania, it is recommended to design the system of the improvement of "Ease of Doing Business" indicators (World Bank, 2014), i.e. to eliminate bureaucratic and business administration barriers, form business-favourable tax environment, reduce the bureaucracy in tax administration, simplify the procedures of the detailed plan, land-use setting and changing.

With reference to EYGM Limited (2013), the attraction of foreign investment is determined by a stable political and legal environment. The absence of timely economic regulation reforms reflects the unstable environment which severely restricts the ability of the government to form business- 
favourable conditions in the country. The increasing importance of FDI in global economies requires a stable and well-adapted FDI regime which would promote welfare and sustainability of the country. Application of laws is one of the ways enabling to create such regime (Bhattacharyya, 2012). Bureaucracy, corruption, information unavailability, lack of trust in partners as well as the lack of competence are recognised as the main negative aspects of the investment environment in Lithuania (Ivestors' Forum Tax Group, 2011). To reduce the rate of corruption the government engages different corruption prevention measures that have been defined in The National Corruption Prevention Program, 2011 2014 (Special Investigation Service of the Republic of Lithuania, 2011). Some of the corruption prevention measures include regulations of procurement, contribution to charity, instructions to public servants, etc., (in total more than 90 measures).

With reference to Ivestors' Forum Tax Group (2011), to successfully compete with foreign countries concerning foreign investment, Lithuania should focus on the improvement of labour regulation and tax environment. Difficult regulation of labour relations is one of the factors restricting FDI attraction. However, skilled and competitive labour force serves as an advantage: the number of people with higher education is one of the highest in Eastern Europe. By global competitiveness rate Lithuania took 48th position among 148 countries in 2013, but the practice of the dismissal and the ability to attract talents lowered the country's position respectively to 130th and 135th positions (World Bank, 2014) by each of the indicators mentioned above. Regarding the tax environment, it should be noted that Lithuania takes 56th position among 189 countries by the index of the attractiveness of the tax system (World Bank, 2014), and the overall tax burden for business reaches $43.1 \%$ tax rate. According to Misiunas and Gudeliauskaite (2013) and Novosinskiene (2013), the introduction of international business favourable tax system is the key factor in seeking for investment promotion in the country.

On the other hand, with reference to DNB (2013), lower level of investment in Lithuania during five recent years can be explained by the uncertainty of the economy and strict policy of credits. By the index of credit availability, Lithuania takes 28th position among 189 countries (World Bank, 2014), thus, the facilitation of credit obtaining terms would serve as an advantage not only for foreign, but also for domestic investors.

The establishment of free economic zones is another factor that would contribute to the attraction of foreign investment in Lithuania. The companies that have been established in free economic zones and have invested more than 1 million Litas do not pay the profit tax during the first reporting periods, and pay $50 \%$ of profit tax (current tariff of profit tax in Lithuania is $15 \%$ ) during further ten reporting periods. What is more, the companies established in free economic zones do not have to pay the real estate tax, and the dividends earned by foreign investors in free economic zones are profit tax free (Invest Lithuania, 2014).
High-level of infrastructure in Lithuania does not impede business and investment performance; well-developed road infrastructure surpasses the quality of the one in the neighbour-countries. The directions of the development of Lithuanian transport and communication sector until 2030 have been defined in The National Transport Development Program, which is the document of the medium-term strategic planning (Ministry of Transport and Communications of the Republic of Lithuania, (2012). With reference to this program, Lithuanian transport and communication system needs to be developed in order to ensure efficient use of national resources thus increasing the competitiveness of the transport sector. The directions of the development of Lithuanian transport and communication sector include modernisation of transEuropean, domestic and local road and rail network, sea water and inland water transport infrastructure, air transport infrastructure, border checkpoints at the external EU borders under the requirements of the Schengen Treaty, and the increase of the quality of logistic and transport services.

However, while improving the infrastructure in the country, the procedures of electricity installation could be accelerated since the country takes only 75 th position by the index of electricity supply (World Bank, 2014).

Summarising, for the attraction of foreign investment the cooperation between public and private sectors is necessary. It should be performed alongside with the efficient investment funding policy and public investment policy (Ginevicius \& Simelyte, 2011). Rather high level of the use of production capacities is one of the main drives for FDI increase, especially combined with the favourable trends of global economic development. However, in order to improve the business and investment environment in Lithuania, it is recommended to eliminate bureaucratic and business administration barriers, form business-favourable tax environment, reduce bureaucracy in tax administration, simplify the procedures of the detailed plan, land-use setting and changing, ensure flexible labour relations and facilitate credit obtaining terms.

\section{CONCLUSION}

Summarising the results of the research, the following conclusions can be made:

- The volume of FDI during the period 2007 - 2013 in Lithuania altered in accordance with the economic cycle: in 2008, FDI in the country decreased by more than $10 \%$ in comparison to 2007 as a result of the beginning of the economic recession; from 2009 to 2013, the volume of FDI in Lithuania increased by almost $20 \%$ as a result of the recovery of developed economies and investment promotion inside the country during the post-crisis period;

- The comparative analysis of the investment environment in Lithuania, Latvia and Estonia has revealed that Lithuania takes the highest position among the Baltic States by "Ease of doing business" indexes in the global context. The advantages of the country in this respect are the favourable conditions to register property, perform contracts and conduct international trade. On the other hand, complicated and prolonged business 
establishment and registry, difficulties obtaining the permission for construction as well as the weak system of investors' protection are considered as main disadvantages of Lithuanian investment environment.

- With reference to the results of the empirical research, the trend and amount of FDI in Lithuania strongly correlate. Linear regression equation is also growing, which proposes that over the next two years FDI in Lithuania should increase. The trend correlation coefficient is high, which proposes that there do not exist many other factors that can have a significant impact on the function.

- Rather high level of the use of production capacities is one of the main drives for FDI increase, especially combined with favourable trends of global economic development. However, in order to improve business and investment environment in Lithuania, it is recommended to eliminate bureaucratic and business administration barriers, form business-favourable tax environment, reduce bureaucracy in tax administration, simplify the procedures of the detailed plan, land-use setting and changing, ensure flexible labour relations and facilitate credit obtaining terms.

\section{REFERENCES}

Agrawal, G., \& Khan, A. (2011). Impact of FDI on GDP: A Comparative Study of China and India. International Journal of Business and Management, 6(10), 71-79. http://dx.doi.org/10.5539/ijbm.v6n10p71

Alam, A., \& Shah, S. (2013). Determinants of foreign direct investment in OECD member countries. Journal of Economic Studies, 40(4), 515527. http://dx.doi.org/10.1108/JES-10-2011-0132

Bhattacharyya, S. (2012). Legal regimes governing foreign direct investment (FDI) in host countries. Advocates for International development. Retrieved Sept. 11, 2014, from http://a4id.org/sites/default/files/user/ documents/FDI\%20Legal\%20Guide.pdf

Boguslauskas, V., Bliekiene, R., Grondskis, G., \& Maksvytis, L. (2009). Econometrics. Regression models. Laboratory works pp. 62-68. Kaunas: Technologija.

Cibinskiene, A., \& Kontautiene, R. (2010). The changes of foreign direct investment flows under the conditions of economic crisis. Journal of Management, 1(17), 291-227.

DNB. (2013). The development and impact of surrounding markets on the economies of the Baltic States. Economic perspectives of the Baltic States. Bank DNB Nord. Retrieved Sept. 12, 2014, from https://www.dnb.lt/sites/default/files/research/baltijos_saliu_ekonomi kos_perspektyvos_2013_ruduo.pdf

EYGM Limited. (2013). Coping with the crisis, the European way. Earnst \& Young's Attractiveness Surveys. Retrieved Sept. 12, 2014, from http://www.ey.com/Publication/vwLUAssets/EuropeanAttractiveness-Survey-2013/\$FILE/European-Attractiveness-Survey2013.pdf

Geizutiene, L., \& Sudzius, V. (2010). Peculiarities of the assessment of company's investment attractiveness. Business Management and Education. Retrieved Sept. 14, 2014, from http://leidykla.vgtu.lt/ conferences/BME_2010/001/pdf/Art-Geizutiene_Sudzius.pdf

Ginevicius, R., \& Simelytè, A. (2011). Theoretical insights in the governmental policies applied for the attraction of foreign direct investment. Business: Theory and practice, 12(3), 225-235.

Goswami, G. G., \& Haider, S. (2014). Does political risk deter FDI inflow? Journal of Economic Studies, 41(2), 233-252.

Indexmundi. (2013). Country comparison. CIA Factbook. Retrieved Sept. 14, 2014, from http://www.indexmundi.com/factbook/compare/ estonia.lithuania/economy

Invest Lithuania. (2014). Foreign direct investment in Lithuania: tendencies and prospectss. ISSUU. Retrieved Sept. 09, 2014, from http://issuu.com/invest_lithuania/docs/tiesiogines-uzsienioinvesticijos-1
Ivestors' Forum Tax Group. (2011). Favourable and clear Lithuanian tax system for everybody. Investors' Forum. Retrieved Sept. 12, 2014, from http://www.investorsforum.lt/files/documents/Investors_forum_LT.pdf

Kok, R., \& Ersoy, B. (2009). Analyses of FDI determinants in developing countries. International Journal of Social Economics, 36(1/2), 105123. http://dx.doi.org/10.1108/03068290910921226

Lithuanian Department of Statistics. (2014). Economic Indicators 31/12/2009 to $31 / 12 / 2013$ [statistics]. Available from Statistics Lithuania Data database.

Ministry of Transport and Communications of the Republic of Lithuania. (2012). Strategical assessment of the impact of the National Transport Development Program on environment. Smart Continent LT. Retrieved Sept. 09, 2014, from http://www.transp.lt/files/uploads/SPAV-ataskaita-galutine.pdf

Misiunas, A., \& Gudeliauskaite, D. (2013). The characteristics of the investment climate in the Baltic States. Lithuanian Journal of Statistics, 52(1), 94-101.

Mucuk, M., \& Demirsel, T. (2013). The effect of foreign direct investments on unemployment: evidence from panel data for seven developing countries. Journal of Business, Economics \& Finance, 2(3), 53-66.

Novosinskiene, A. (2013). Assessment of Lithuanian tax system considering the aspect of the fiscal function. Agricultural sciences, 20(3), 222229 .

Rao, S. (2010). Investment Climate in Fragile and Conflict Affected States (GSDRC Helpdesk Research Report 713). Birmingham, UK: GSDRC, University of Birmingham. Retrieved Sept. 14, 2014, from http://www.gsdrc.org/docs/open/HD713.pdf

Rogmans, T., \& Ebbers, H. (2013). The determinants of foreign direct investment in the Middle East North Africa region. International Journal of Emerging Markets, 8(3), 240-257. http://dx.doi.org/10.1108/17468801311330310

Santander Trade (2014). Lithuania: foreign investment. Santander Trade Portal. Retrieved Sept. 10, 2014, from https://en.santandertrade.com/establish-

overseas/lithuania/investing?\&actualiser_id_banque=oui\&id_banque $=0 \&$ memoriser_choix $=$ memoriser

Special Investigation Service of the Republic of Lithuania. (2011). The National Corruption Prevention Program 2011 - 2014. SIS. Retrieved Sept. 23, 2014, from http://www.stt.lt/lt/nkkp-2011-2014/

Tavares-Lehmann, A. T., Coelho, A., \& Lehmann, F. (2013). Taxes and Foreign Direct Investment Attraction: a Literature Review. New Policy Challenges for European Multinationals (Progress in International Business Research), 7, 89-117. http://dx.doi.org/10.1108/S1745-8862(2012)0000007007

The Central Bank of the Republic of Lithuania. (2013). The Review of Lithuanian Economics 31/12/2009 to 31/12/2013 [statistics]. Available from LB Data database.

The Government of the Republic of Lithuania. (2014). The program of investment promotion and industrial development for 2014-2020. GRL. Retrieved Sept. 20, 2014, from http://raseiniusvietimocentras.lt/testas/wpcontent/uploads/2014/01/investiciju-programa.pdf

United Nations. (2014). Global Investment Trends Monitor No. 15. UN. Retrieved Sept. 09, 2014, from http://unctad.org/en/ PublicationsLibrary/webdiaeia2014d1_en.pdf

Word Bank. (2014). Economy rankings. WB. Retrieved Sept. 09, 2014, from http://www.doingbusiness.org/rankings

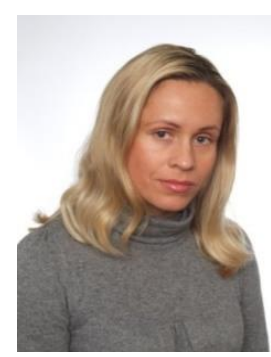

Ligita Gaspareniene received the $\mathrm{PhD}$ degree and the Master in Law in 2009 and 2013 respectively. Her main research fields are outsourcing, financial markets, financial investment.

She is currently an Associate Professor with the Kaunas University of Technology, and Mykolas Romeris University. She has published over 23 papers.

Address: Mykolas Romeris University, Ateities str. 20, Vilnius, Lithuania.

E-mail: ligitagaspareniene@mruni.eu 